\title{
Use of electronic resources by students in a premier postgraduate theological university in Ghana
}

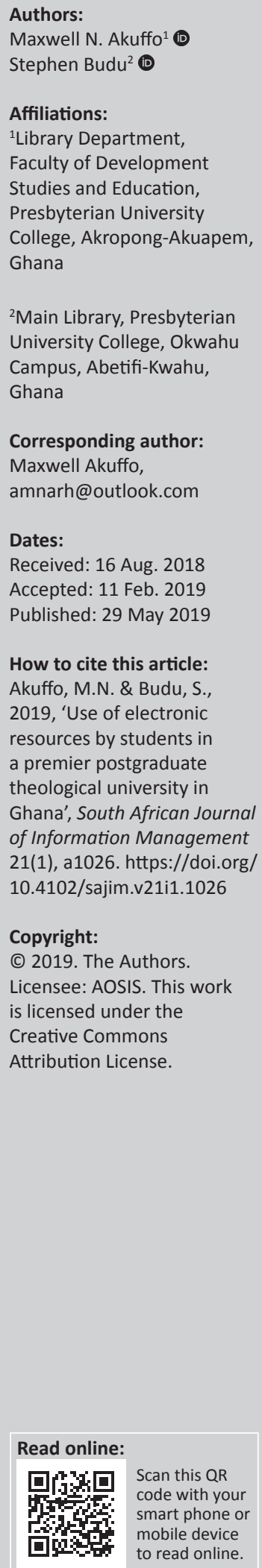

Background: Most electronic resource (e-resource) studies have been undertaken in universities because e-resources are crucial in enhancing students' research and learning activities. However, there is a paucity of e-resources research in postgraduate theological universities, particularly in Ghana. This study, therefore, investigated students' level of use of e-resources at the AkrofiChristaller Institute of Theology, Mission and Culture.

Objectives: The study's specific objectives were to identify the types of e-resources available for use, discover the extent of awareness of e-resources, find out how e-resources were accessed and used, ascertain the purposes of using e-resources and identify the benefits of and problems in using e-resources.

Method: Using the survey research design, copies of the questionnaire were administered to 33 postgraduate students by accidental sampling. Data analysed using Microsoft Excel 2013 were mainly presented as frequency and percentage distributions.

Results: The study revealed high awareness levels, adequate computer competencies, derivation of multiple benefits, use of e-resources for academic purposes and inadequate search skills of most respondents because of the dearth of training. Constraints to e-resources usage were access problems, search and retrieval problems and staff-related problems.

Conclusion: The study informs university administrators and libraries about the need to ensure students leverage e-resources in research and studies. The study proposed, among other recommendations, the provision of regular and mandatory information literacy training for students, the need for the institute's library staff to provide personalised search support to students and the provision of off-campus access to the institute's e-resource subscriptions.

Keywords: Extent of use; electronic resources; students; postgraduate theological university; Ghana.

\section{Introduction}

The inability of print-based materials to meet all academic needs makes it imperative for academic libraries to prioritise the provision of electronic resources (e-resources) in their collection management efforts. Rolinson, Meadows and Smith (1995) emphasise the need for the use of computer-based information in research. Rassiya and Chinnasamy (2014:140) state that e-resources are electronic information storage systems accessed via electronic systems and computer networks. According to the International Federation of Library Associations and Institutions (IFLA) (2012:3), e-resources are materials that need access either remotely (via the Internet using a personal computer or mainframe or handheld mobile device) or locally.

The use of e-resources, a prevalent phenomenon in universities, is crucial as it enables the enhancement of academic work (Deng 2010:97). The need arises, therefore for postgraduate students, whose studies focus on the conduct of research, to maximise the use of e-resources in their studies. While some studies in Ghana (Borteye \& Dadzie 2015; Kwadzo 2015), Nigeria (Akporhonor \& Akpojotor 2016) and Uganda (Okello-Obura 2010), for example, have investigated e-resource utilisation among postgraduate students, e-resource research in postgraduate theological universities, including the very few ones in Ghana, appears to be inadequate. The Akrofi-Christaller Institute of Theology, Mission and Culture (ACI), Ghana's premier theological university with a charter to award only postgraduate degrees, provides staff and students with access to various e-resources (to aid teaching, research and learning) through the Consortium of Academic and Research Libraries in Ghana (CARLIGH). The consortium enables member academic libraries to harness resources for the provision of adequate information to users 
(Dzandza \& Alemna 2011:20). This research seeks to ascertain the extent to which ACI students are using e-resources in their research and learning activities.

\section{Brief overview of the Akrofi- Christaller Institute of Theology, Mission and Culture}

The ACI was officially founded as an autonomous charitable institution in 1987 by the Presbyterian Church of Ghana and is located at Akropong-Akuapem in the Eastern Region of Ghana. It is a postgraduate research and training institute, which studies and documents Ghanaian and African Christian history, thought and life. The ACI is fully accredited by the National Accreditation Board of the Ministry of Education of Ghana as a tertiary institution with a presidential charter to award degrees (ACI 2016a). The institute currently runs and awards the following degrees: Master of Arts in Theology and Mission, with options in Historic Mission and Development, Biblical Studies and Pentecostal Studies; Master of Theology, with options in African Christianity, and Biblical Translation and Interpretation; and Doctor of Philosophy in Theology (ACI 2016b).

\section{E-resource environment at the Akrofi-Christaller Institute of Theology, Mission and Culture}

The Johannes Zimmermann Library of the ACI has various print and e-journals and online scholarly databases (such as JSTOR, EBSCOhost and Open Access Theses and Dissertations) that are utilised by students and staff to meet their teaching, research and learning needs. The purpose-built three-storey reference library currently holds over 20000 computerised books covering the academic and pastoral disciplines and research projects of the institute. The collections comprise Ghanaian language writings from the mid-nineteenth century and historical, religious and cultural studies. Facilities available at the library to aid in effective use of e-resources include a customised library catalogue known as 'Alice'; eight state-ofthe-art desktop computers with Internet connectivity for students' research and studies; and an audio-visual archive. To augment the library's services, the ACI also operates a modern information communication technology (ICT) centre (with a power plant that enables nine networked computers to regularly provide wireless Internet access) where students conveniently access various e-resources (ACI 2016c).

\section{Problem statement}

As noted earlier, the ACI has subscribed to various e-resources through CARLIGH for staff and students. To facilitate access and use, the institute has also provided the requisite technology and an enabling e-resource environment. Despite these initiatives, a preliminary investigation revealed that a major constraint to e-resources access and use has been intermittent technical glitches resulting in slow Internet speed, which tends to limit access to scholarly literature over the Internet. Consequently, ACI students face the risk of not leveraging e-resources to meet their research and learning needs. This problem, coupled with the paucity of e-resources research in chartered postgraduate theological institutions, particularly in Ghana, makes it imperative that an evidencebased research study should be conducted to investigate students' level of use of e-resources at the ACI.

\section{Research questions}

Attempts were made to answer the following research questions (RQ):

- RQ1: What types of e-resources are available for use by postgraduate students?

- RQ2: To what extent are postgraduate students aware of e-resources subscribed to by the ACI?

- RQ3: How do postgraduate students leverage ICTs to effectively access and use e-resources?

- RQ4: For what purpose(s) do postgraduate students use e-resources in their studies?

- RQ5: What are the benefits that motivate postgraduate students to use e-resources in their studies?

- RQ6: What problems do postgraduate students encounter in accessing e-resources that they use?

\section{Literature review}

Literature on e-resources is reviewed under relevant themes below. The first part of the review covers types and access, followed by the benefits and purposes, and then the use (comprising a discussion of factors such as awareness, skill sets and challenges) of e-resources. The review also consists of an assessment of e-resources provision and use. The final part of the review deals with the focus of e-resource studies and the identification of research gap.

E-resources come in various types and forms, including e-journals; electronic databases (such as full-text databases, indexing and abstracting databases, numeric and statistical databases, and reference databases); biographies; dictionaries; directories and encyclopaedias; e-books; e-images; and e-audio and visual resources (IFLA 2012:3). Access to e-resources is obtained either on campus or off campus (Amankwah 2014; Rassiya \& Chinnasamy 2014:142), or at multiple locations (Deng 2010:92) using electronic devices, such as desktop computers, laptops, iPads and/or tablets and mobile phones (Amankwah 2014). Other modes of access include search engines, meta search engines, information gateways, subject directories, scholarly databases (Dadzie 2005:293-294; Kwadzo 2015:16; Kwafoa, Imoro \& Afful-Arthur 2014:10) and library catalogue (Amankwah 2014; Deng 2010:93).

E-resources are invaluable tools for research (Heterick 2002:10) - gathering data, information and facts for knowledge advancement (Shuttleworth 2008: Definition section) and learning - 'the acquisition of knowledge or skills through study, experience, or being taught' (English Oxford Living Dictionaries 2016: Definition section: para. 1). E-resources complement traditional print-based materials 
(Dadzie 2005:290) and ensure the maintenance of updated information, convenience and global distribution (Dadzie 2005:290; Vasishta \& Jyoti 2007). They also ensure space saving, rapid and accurate information retrieval, multi-user access, compatibility with search engines and manageability (Vasishta \& Jyoti 2007). These benefits have necessitated the provision of hi-tech environments for students and staff to widely access and use e-resources for various purposes in the United Kingdom (Rolinson et al. 1995), Scotland (De Vicente, Crawford \& Clink 2004), Saudi Arabia (Al-Shanbari \& Meadows 1995), USA (Kaminer 1997), Tanzania (Manda 2005), Botswana (Ojedokun \& Owolabi 2003), Nigeria (Nwezeh 2010) and Ghana (Dadzie 2005). For example, e-resources are used for educational (Amankwah 2014; Dadzie 2005:293) or academic, personal, official and communication purposes, as well as for finding relevant materials and gaining current and general information on new developments (Kwafoa et al. 2014:7; Tahir, Mahmood \& Shafique 2010:129-131) or specific topics (Deng 2010:94).

The role of e-resources, especially in enhancing students' research and learning activities (Amankwah 2014), has gained prominence globally. This phenomenon is evidenced by some studies undertaken in Australia (Deng 2010), France (Vibert et al. 2007), Kuwait (Al-Ansari 2006), Pakistan (Tahir et al. 2010), West Indies (Renwick 2005), Nigeria (Ani, Edem \& Ottong 2010; Ozoemelem 2009) and Ghana (Borteye \& Dadzie 2015; Kwadzo 2015; Obeng-Koranteng \& Dzandu 2013). Among the factors that account for high use of e-resources are freely available access, ease of use, currency (De Vicente et al. 2004, in Dadzie 2005:291; Falk 2003, in Gakibayo, IkojaOdongo \& Okello-Obura 2013:16) and advancement in ICTs (Deng 2010:96; Tahir et al. 2010:133). Other factors include high skill levels (Ani et al. 2010:543) and high awareness levels (Borteye \& Dadzie 2015; Yang \& Li 2015).

Despite the above-mentioned developments, studies by Amankwah (2014) and Kwafoa et al. (2014:15) revealed that the use of e-resources has been low in some Ghanaian universities. Akussah, Asante and Adu-Sarkodee (2015:37) and Gakibayo et al. (2013:17) attributed this situation to the lack of awareness of availability of e-resources. The situation has also been attributed to the lack of ICT (Ozoemelem 2009:8; Watts \& Ibegbulam 2006:59) or search skills (Amankwah 2014; Gakibayo et al. 2013:17), arising from the lack of formal training (Tahir et al. 2010:133) and inadequate ICT infrastructure or poor e-information environments (Ani et al. 2010:541-542; Ani, Ngulube \& Onyancha 2014:170; Watts \& Ibegbulam 2006:59). The low use of e-resources has been further attributed to the lack of access to scholarly databases, which emanates from slow Internet speed, high cost of Internet use (Kwafoa et al. 2014:13) and frequent power cuts (Amankwah 2014; Obeng-Koranteng \& Dzandu 2013). These challenges can be addressed by improving computer skills (Okello-Obura 2010:103) and power supply (Bashorun, Isah \& Adisa 2011:561), as well as expanding ICT facilities (Gakibayo et al. 2013:19; Kwafoa et al. 2014:16). They can be addressed also by intensifying awareness creation (Akussah et al. 2015:37; Kwadzo 2015:24) through training
(Bashorun et al. 2011:560; Gakibayo et al. 2013:16) in the form of workshops (Bashorun et al. 2011:560), orientation programmes and seminars (Akussah et al. 2015:37; Gakibayo et al. 2013:19).

While some institutions have provided adequate ICT infrastructure and created awareness to ensure effective use, other institutions have neither maximised the use of ICTs nor created awareness. It is worth noting that the availability of e-resources does not necessarily ensure usage (Kwafoa et al. 2014:4). Moreover, students' levels of computer competency (Gakibayo et al. 2013:11; Okello-Obura \& Magara 2008, in Okello-Obura 2010:103) and information literacy skills (Okello-Obura 2010:103) affect the extent to which they access e-resources. As a result, there are variations in terms of how technology is provided for use of e-resources, and in terms of the levels of awareness, skills, access, use and impact. For instance, while Borteye and Dadzie (2015) ascertained that despite high levels of awareness and usage, students' attitude towards open access journals was not very positive, Dadzie and Van der Walt (2015) established that digital resources impacted faculty members positively despite low levels of awareness and usage.

Most of the e-resource studies have been undertaken in universities. Some have targeted postgraduate (Akporhonor \& Akpojotor 2016; Borteye \& Dadzie 2015; Kwadzo 2015; Okello-Obura 2010; Okello-Obura \& Ikoja-Odongo 2010; Ozoemelem 2009) and undergraduate students (Amankwah 2014). Others have targeted staff, such as administrators and faculty members (Kwafoa et al. 2014), faculty and research staff (Okiki 2012; Tahir et al. 2010) and research scientists (Obeng-Koranteng \& Dzandu 2013). Akussah et al. (2015) and Deng (2010) have used both staff (faculty and administrators) and students as samples in their studies. Neither the studies in Ghana (Akussah et al. 2015; Amankwah 2014; Borteye \& Dadzie 2015; Kwadzo 2015; Kwafoa et al. 2014; Obeng-Koranteng \& Dzandu 2013) nor those in other countries have investigated postgraduate students' use of e-resources in any of the few private theological universities in existence, most particularly at the premier chartered theological university in Ghana.

\section{Theoretical framework}

This study was guided by Davis' (1989:320) technology acceptance model (TAM), which explains the factors that influence users' decisions to use ICTs. The model posits that two factors that are crucial in determining ICT use are perceived usefulness (PU) and perceived ease of use (PEOU) (Thistoll 2011:263). Venkatesh et al. (2003:455) have expanded TAM to include a third construct: attitude towards using technology (ATUT). That is, when users have new technologies, decisions regarding the mode and time to use them are influenced by factors such as PU, PEOU (Davis 1989:320; Kalusopa 2011:55) and ATUT (Venkatesh et al. 2003:455). Perceived usefulness is the extent to which one anticipates benefits will be derived when one uses a technology and PEOU is the extent to which one anticipates 
one will be able to use a technology without any obstacle or hindrance (Davis 1989:320). Attitude towards using technology is one's general behaviour towards the use of a technology (Venkatesh et al. 2003:455).

The technology acceptance model was relevant to investigate the level of use of e-resources for research and learning activities among students of the ACI. The model specifically helped to determine students' awareness levels, how they accessed and used e-resources, the purposes of using e-resources and how they benefited from using e-resources. Thus, the variables relevant to the study include usefulness (students' use and benefits of e-resources), constraints to use (challenges students faced in using e-resources), attitude towards use (students' attitude) and external variables (e.g. ICT skills required to use e-resources and availability of infrastructure or technologies).

\section{Methodology}

A survey research design was adopted for the study based on its suitability in helping to find answers to almost all the 'what' questions the study sought to answer (Yin 2003:6), as well as to better understand the analysis of quantitative data the researchers envisaged collecting (Saunders, Lewis \& Thornhill 2012:177). The ACI was selected as a study setting because it is one of the few Ghanaian private universities that has been granted a presidential charter to award degrees and is the first private theological university to offer accredited doctoral programmes in Ghana. In addition, students of the $\mathrm{ACI}$ have access to a variety of e-resources as well as regular Internet facilities and other associated technologies. Moreover, the researchers envisaged that it would be easier and more convenient to collect data at the ACI because of its close proximity to the first author's workplace. Postgraduate students were the target population for the study. The proportionate sampling method was used to sample 33 students representing $40 \%$ of the total postgraduate student population of 83 , after which the convenience or accidental sampling technique was used to select the respondents. The challenge of locating the respondents (Kumar 2005:178) most of whom worked as pastors and all of whom resided at different off-campus locations - influenced the choice of sampling by convenience. The use of convenience sampling, therefore, enabled the researchers to easily obtain the respondents (Saunders et al. 2012:282).

The questionnaire, usually associated with the survey research design (Saunders et al. 2012:177), was the instrument for data collection. Permission was sought from the Registrar of the ACI prior to data collection in May 2016. The researchers administered copies of the questionnaire to postgraduate students who were randomly met at the Johannes Zimmermann Library and were willing to participate in the study until the required sample size of 33 was achieved. Few of the completed questionnaires were received immediately from the respondents, while most of the completed ones were received 2 days after distribution. Completed questionnaires were checked for consistency and the responses were coded. Data were analysed using
Microsoft Excel 2013. The results were mainly presented as frequency and percentage distributions.

\section{Results and discussion}

This section presents and discusses the results of the study under six themes. These include background of respondents, awareness of the types of e-resources available for use by postgraduate students, access to and use of e-resources by postgraduate students, purposes of using e-resources by postgraduate students, benefits motivating the use of e-resources by postgraduate students and problems encountered in accessing e-resources used by postgraduate students.

\section{Background of respondents}

Of the 33 respondents surveyed, 25 (75.8\%) were men and 8 $(24.2 \%)$ were women. Twenty-eight $(84.8 \%)$ respondents pursued master's degrees: 19 (57.5\%) studied Master of Arts in Theology and Mission and $9(27.3 \%)$ studied Master of Theology. Only five (15.2\%) respondents pursued doctoral level studies, that is, Doctor of Philosophy in Theology. It is evident from the findings that more responses were elicited from male respondents than from female respondents. Also, most of the respondents were master's level students who studied Master of Arts in Theology and Mission.

\section{Awareness of the types of e-resources available for use by postgraduate students}

The study revealed a very high level of awareness of the availability of e-resources among ACI students. That is, all 33 respondents were aware of the available e-resources and each of them was aware of more than one e-resource. Awareness of online dissertations or theses ranked the highest, while that of e-books ranked the lowest. The students also rated their levels of awareness as high. A list of the types of e-resources of which students were aware includes online dissertations or theses $(30 ; 90.9 \%)$, e-journals $(28 ; 84.8 \%)$, search engines $(27 ; 81.8 \%)$, library catalogue $(25 ; 75.8 \%)$, academic databases $(25 ; 75.8 \%)$, website information $(22 ; 66.7 \%)$, emails $(16 ; 48.5 \%)$ and e-books (10; 30.3\%). Borteye and Dadzie (2015) and Yang and Li (2015) also ascertained high awareness levels in the University of Ghana and the Texas A\&M University, respectively. Conversely, Akussah et al.'s (2015:37) study in two Ghanaian academic libraries and Gakibayo et al.'s (2013:17) study in a Ugandan academic library found that awareness of e-resources was low.

With respect to how they became aware of available e-resources, 20 (60.6\%) respondents said they became aware after attending orientation or training programmes organised by the Johannes Zimmermann Library staff. Besides, eight (24.2\%) respondents indicated that they were notified by their colleagues or lecturers and five (15.2\%) indicated having read the library guide or newsletters or flyers or posters. It can be inferred that although a total of $13(39.4 \%)$ respondents became aware without attending library orientation or training programmes, the existence of annual 
library orientation (for new students) and informal library training programmes for students mainly accounted for the high level of awareness. Moreover, the respondents' ability to list the types of e-resources of which they were aware means that they had ample knowledge of e-resources needed for research and learning.

\section{Access to and use of e-resources by postgraduate students}

The study found that like Deng's (2010) finding revealed in an Australian higher education setting, e-resources were accessed either at a single location (campus) or at multiple locations (on-campus and off-campus). All the respondents accessed e-resources at the Johannes Zimmermann Library, while two-thirds accessed them at the ACI ICT Centre. On-campus access, which involved accessing e-resources at the Library and the ICT Centre, was more convenient and highly patronised. It is worth noting that off-campus access to ACI-subscribed e-resources was not provided by the ACI. Sixteen $(48.5 \%)$ respondents accessed e-resources at the Library and the ICT Centre; 11 (33.3\%) accessed them at the Library; 3 (9.1\%) accessed them at the Library, the ICT Centre and at home; and another $3(9.1 \%)$ accessed them at the Library, the ICT Centre and Internet cafes. The findings of Amankwah (2014) and Rassiya and Chinnasamy (2014:142), in research conducted at a Ghanaian public university and an Indian public university (academic) library; respectively, also revealed both on-campus and offcampus access. The availability of desktop computers with reliable Internet access, coupled with the provision of regular power supply, afforded the students convenient access to e-resources for their research and studies on campus. The very few respondents who accessed e-resources off-campus did so either at their homes or at Internet cafes outside the ACI, where most of the on-campus facilities were non-existent.

Again, the study established that the respondents used at least one of four electronic devices - desktops, laptops, iPads and/or tablets and mobile phones - for access, with most of them using their personal electronic devices (mainly laptops). This finding, corroborated by Amankwah's (2014) study, is evidenced by these responses: $15(45.5 \%)$ respondents said they used laptops only, 8 (24.2\%) said they used iPads and/ or tablets only and $4(12.1 \%)$ mentioned they used laptops, iPads and/or tablets and mobile phones. The rest of the respondents said they used desktop computers only 3 (9.1\%), desktop computers and laptops $2(6.1 \%)$ and laptops and mobile phones $1(3 \%)$. The use of multiple electronic devices provided students with alternative means of access. For instance, they could use the desktop computers at the ACI to aid access to e-resources for effective studies whenever they experienced power cuts at home or they had difficulty in accessing e-resources using their personal laptops and iPads and/or tablets.

As computer skills affect access to e-resources (Gakibayo et al. 2013:11), the study, further probing the level of computer skills that respondents had attained, revealed that $26(78.8 \%)$ respondents had intermediate computer skills, 4 (12.1\%) had basic computer skills and $3(9.1 \%)$ had advanced computer skills. Similarly, Gakibayo et al.'s (2013:16) study discovered that most of the respondents had intermediate computer skills. This finding shows that the level of computer skills was adequate because all the respondents had acquired the minimum or basic skills needed to use electronic devices to improve access to e-resources. The finding agrees with the discovery of adequate computer skills by Okiki (2012:4) in a study undertaken at the University of Lagos, Nigeria, but contradicts with Ozoemelem's (2009:8) study finding conducted in Delta State University (Nigeria). Their adequate computer competency saved students the time of having to rely on the institute's library and ICT staff for assistance and, therefore, enhanced their research and learning activities.

The students accessed e-resources by searching the library catalogue, and through 16 academic databases and two search engines. The types of search engines used were Google and Yahoo! Search. As stated earlier, the library catalogue (Alice) is a customised library software. Thirteen of the 16 academic databases subscribed to by the ACI through CARLIGH, and three open access ones, were generally used. Besides, twothirds (22 or $66.7 \%$ ) of the respondents accessed search engines and academic databases, and one-third (11 or 33.3\%) accessed academic databases and the library catalogue. The respondents mainly accessed (searched e-resources within) academic databases that have subjects offered in the ACI (such as religion, theology, culture and research methods) as some of their favourite subjects and, therefore, relate to ACI academic disciplines. The respondents accessed the following 10 scholarly databases without usernames and passwords: JSTOR, Project Muse, Emerald, BIOONE, Oxford University Press Online Journals, Taylor \& Francis Online, Sage Research Methods, Credo Reference, Cambridge University Press and World Bank e-Library. The other three ACI-subscribed databases that students accessed with usernames and passwords included AGORA, EBSCOhost and SAGE Journals. In the case of the open access databases, the students used the following: Yale University Digitisation Project, Papers of Stephen D. Morad - Collection 689, and Open Access Theses and Dissertations.

Despite the adequate computer competency levels acquired, most of the respondents lacked adequate search skills because the annual informal training provided by the institute's library staff was not adequate to equip students with skills to conduct searches within the search engines and academic databases. Twenty-five $(75.8 \%)$ respondents stated that their search skill levels were low, while eight $(24.2 \%)$ indicated that their search skill levels were high. Similar studies in Ghanaian (Kwafoa et al. 2014:13) and Pakistani (Tahir et al. 2010:133) universities have also established that majority of respondents lacked adequate skills to access e-resources. The high skill levels of a few of the respondents were as a result of adequate e-resources training they had received prior to 
enrolling at the institute. Of the 25 respondents, 21 attributed their low search skill levels to inadequate e-resources training they had attended at the Johannes Zimmermann Library, a situation that necessitates the provision of regular training. In Ghana, Amankwah (2014) and Kwafoa et al. (2014:13) also identified the lack of formal training. In contrast to TAM's (Davis 1989:320) perception of ICTs as capable of being easily used, the low search skill levels hindered attempts by the students to retrieve some relevant and up-to-date e-resources to support research and learning. It is, therefore, imperative that students must be equipped with the needed skills to access e-resources. The acquisition of information literacy skills is essential for accessing e-resources (Okello-Obura 2010:104)

Searches were usually conducted independently, or with assistance from the library staff or colleagues. While almost a quarter (8 or $24.2 \%$ ) of the respondents conducted searches themselves, almost half ( 16 or $48.5 \%)$ were assisted by the library staff, and slightly less than one-third ( 9 or $27.3 \%$ ) were assisted by their colleagues. This finding shows that most of the respondents were unable to conduct searches independently. Again, this finding reinforces the earlier finding that most respondents have lacked adequate search skills.

\section{Purposes of using e-resources by postgraduate students}

Consistent with the findings of Amankwah (2014) and Kwafoa et al. (2014:7) in Ghana and Deng (2010:94) in Australia, the various e-resources were used mainly for academic purposes. All 33 students used them to enhance their research activities, that is, to aid in reviewing literature, and more than three-quarters $(87.9 \%)$ used e-resources for completing assignments. Besides, every student used e-resources for not less than two purposes. Hence, the purposes of using e-resources were multi-dimensional (Rehman \& Ramzy 2004, in Deng 2010:94). Notwithstanding the skills limitation of most students, the decision to still use e-resources was informed by their perceptions of e-resources as capable of serving many academic purposes. Eighteen (54.5\%) respondents used e-resources to enable them to review literature, complete assignments and gain information on specific topics. Six (18.2\%) indicated they used e-resources for literature review, completing assignments and supplementing study notes. In addition, five (15.2\%) stated they used e-resources to aid in reviewing literature and completing assignments. Four (12.1\%) also said they used e-resources to review literature and supplement their study notes. Table 1 depicts the frequency and percentage of responses to the purposes of using e-resources.

TABLE 1: Purposes of using e-resources by postgraduate students.

\begin{tabular}{lcc}
\hline Purpose & Frequency & $\% \dagger$ \\
\hline To review literature & 33 & 100 \\
To complete assignments & 29 & 87.9 \\
To gain information on specific topics & 18 & 54.5 \\
To supplement study notes & 10 & 30.3 \\
\hline
\end{tabular}

$\dagger$, Percentage computed on the basis of multiple responses provided by the respondents.

\section{Benefits motivating the use of e-resources by postgraduate students}

On the issue of the benefits derived, the study revealed that even though most students had inadequate search skills, they still used e-resources because of the PU to their studies. According to TAM, one is inspired to use ICTs when one anticipates there are benefits to be derived (Davis 1989:320). The students showed that they derived multiple benefits from using e-resources. Nineteen $(57.6 \%)$ students were inspired to use e-resources because of the availability of search tools. Sixteen (48.5\%) indicated that multiple users could access e-resources concurrently; 14 (42.4\%) mentioned benefits relating to time saving; and 11 (33.3\%) stated that compared to print sources, e-resources are less bulky - hence, accessing and using them helped save space. Moreover, $10(30.3 \%)$ said that they could use e-resources at their own convenience, that is, they benefited from the easy-to-use feature of e-resources, while $8(24.2 \%)$ stated that many support facilities were available to facilitate access. Table 2 illustrates the results obtained on the benefits that motivated students to use e-resources.

\section{Problems encountered in accessing e-resources used by postgraduate students}

Regarding the problems encountered, a total of 83 responses were elicited from all 33 respondents, indicating that they were constrained by multiple problems in accessing e-resources. The researchers have grouped these problems under three categories identified by Okello-Obura (2010:102): access problems, literacy and search problems, and other problems (the last one adapted in this study as staff-related problems). Even though TAM perceives ICTs to be used without any hindrance (Davis 1989:320), the ICTs, skill sets and assistance the ACI provided were not adequate to ensure easy access. Also, some of the students resorted to off-campus access, thus aggravating their access problems. It can be deduced, therefore, that inability on the part of the students and inadequate institutional support were major factors that affected the students in accessing e-resources they used. Similarly, Kalusopa (2011:56), aiming to understand the factors influencing ICTs uptake and use in Botswana's labour sector, critiqued the practicability of TAM's PEOU construct on the grounds that using ICTs could be impeded by factors such as inability, time and institutional barriers.

While frequent power cuts outside the $\mathrm{ACI}$ and high cost of Internet use off-campus were cited, it came to light that slow

TABLE 2: Benefits motivating the use of e-resources by postgraduate students.

\begin{tabular}{lcc}
\hline Benefit & Frequency & $\% \dagger$ \\
\hline Availability of search tools & 19 & 57.6 \\
Multi-user access & 16 & 48.5 \\
Time saving & 14 & 42.4 \\
Space saving & 11 & 33.3 \\
Ease of use & 10 & 30.3 \\
Availability of support facilities & 8 & 24.2 \\
\hline
\end{tabular}

$\dagger$, Percentage computed on the basis of multiple responses provided by the respondents. 
Internet speed, lack of off-campus access to ACI-subscribed e-resources and inadequate networked computers were most common among the access problems. In the case of the literacy and search problems, the respondents lacked adequate knowledge and/or skills to formulate search strategies, to use advanced search options and to evaluate e-resources. The staff-related problems were unwillingness of some library staff to assist students to facilitate access and inability of some library staff to assist students with search and retrieval skills. The frequency and percentage of responses to the problems which constrained the use of e-resources are represented in Table 3.

\section{Conclusion}

\section{Summary of major findings}

The results have shown that postgraduate students were very much aware of ACI-subscribed e-resources, from which they derived multiple benefits, and which they used often for academic purposes. Thus, the extent of use of e-resources reflected the multiple benefits derived, as well as the level of awareness. Despite the students' adequate computer competencies, and contrary to TAM's PEOU construct, most of them lacked adequate skills for access because of inadequate training in the use of e-resources. Inability and inadequate institutional support were identified as the main factors that affected access to e-resources. Also, despite some attempts at providing various e-resources and needed facilities, the ACI lacked off-campus access to its subscribed e-resources. These phenomena have been aggravated by frequent interruptions in electricity supply at off-campus locations (homes and Internet cafes) and slow Internet speed, among other problems. However, the students continued to use e-resources because of the PU of e-resources to their studies.

\section{Recommendations}

To improve the provision of e-resources to support research and learning activities, the ACI needs to address the above-mentioned problems by paying attention to some recommendations. These include the following: firstly, the Johannes Zimmermann Library, on behalf of ACI, should identify training needs of its staff and provide them with regular or continuous training by sponsoring them to attend CARLIGH's conferences, workshops and seminars to enhance their knowledge and skills regarding e-resources access and usage. The staff should, in turn, equip students with innovative methods and techniques of searching to easily formulate search strategies, use advanced search options, and evaluate and retrieve e-resources on a timely basis to meet their educational needs. This can be achieved through the provision of regular and mandatory information literacy training aimed at enabling students to acquire knowledge and skills needed to seek, locate, evaluate and use information effectively to fully meet their educational needs.
TABLE 3: Problems encountered in accessing e-resources used by postgraduate students.

\begin{tabular}{|c|c|c|}
\hline Problem category or type & Frequency & $\% \dagger$ \\
\hline \multicolumn{3}{|l|}{ Access problems } \\
\hline Slow Internet speed & 14 & 42.4 \\
\hline Lack of off-campus access to ACl-subscribed e-resources & 13 & 39.4 \\
\hline Inadequate networked computers & 10 & 30.3 \\
\hline Frequent power cuts outside the $\mathrm{ACl}$ & 8 & 24.2 \\
\hline High costs associated with Internet use outside the $\mathrm{ACl}$ & 6 & 18.2 \\
\hline \multicolumn{3}{|l|}{ Literacy and search problems } \\
\hline Lack of adequate skills to formulate search strategies & 9 & 27.3 \\
\hline Lack of adequate skills to use advanced search options & 8 & 24.2 \\
\hline Lack of adequate knowledge and skills to evaluate e-resources & 8 & 24.2 \\
\hline \multicolumn{3}{|l|}{ Staff-related problems } \\
\hline Library staff's unwillingness to assist students to facilitate access & 4 & 12.1 \\
\hline $\begin{array}{l}\text { Library staff's inability to assist students with search and } \\
\text { retrieval skills }\end{array}$ & 3 & 9.1 \\
\hline
\end{tabular}

$\dagger$, Percentage computed on the basis of multiple responses provided by the respondents.

Secondly, the management of ACI should inculcate in the library staff the need to always provide personalised support to students in their search activities. The institute's library staff should, therefore, be encouraged to provide custom search services. That is, students should be provided with forms to make search requests, and staff should be willing to assist them to conduct searches. Also, copies of flyers with self-help guides for accessing or searching within the library catalogue, academic databases and search engines should be made available at the ACI Library and ICT Centre, and on the ACI Library's website. The willingness of library staff to assist students will not only inspire students to access e-resources but also enable them to spend less time in accessing and retrieving the e-resources they need and, thus, enhance their research and studies.

Thirdly, it is recommended for the librarian to present a proposal to the management of ACI requesting funds to be allocated for the provision of off-campus access to e-resources through a remote access system known as 'EZproxy'. As ACI students are not resident on campus, the system will be beneficial in helping to meet the students' research needs and enabling them to gain access to the library's e-resource subscriptions at off-campus locations.

Fourthly, it is imperative to improve the Internet with the fastest speed possible to increase access to e-resources. While the use of full Internet bandwidth is perhaps the most effective method, using third-party software or the latest version of Internet Download Manager to increase download speed and removing garbage from the computer by downloading CCleaner software for free will ultimately have an effect on Internet speed.

To conclude, there is a need to increase the number of computers at the library. The librarian should either present a request to the management of $\mathrm{ACI}$ to provide funds for the procurement of additional state-of-the-art computers or write to donor agencies for support. 


\section{Acknowledgements}

The authors are grateful to the editorial staff, the three anonymous reviewers, the publisher and the support staff of SAJIM and AOSIS Publishing for contributing to the highest publishable standard of the article.

\section{Competing interests}

The authors declare that they have no financial or personal relationship(s) which may have inappropriately influenced them in writing this article.

\section{Author's contributions}

M.N.A. revised the entire work for publication. S.B. was responsible for the initial research.

\section{References}

ACl, 2016a, About ACl, viewed 07 November 2016, from http://www.acighana.org/ site/aboutus/index.php

ACl, 2016b, ACl: Academic programmes, viewed 07 November 2016, from http:// www.acighana.org/site/academics/index.php

ACl, 2016c, ACl: Johannes Zimmermann Library, viewed 07 November 2016, from http://www.acighana.org/site/library/index.php

Akporhonor, B.A. \& Akpojotor, L.O., 2016, 'Challenges confronting postgraduate library and information science students in the use of electronic resources in Southern Nigeria', Library Philosophy and Practice (e-journal) 1319, 1-19, viewed 18 April 2017, from http://digitalcommons.unl.edu/libphilprac/1319

Akussah, M., Asante, E. \& Adu-Sarkodee, R., 2015, 'Impact of electronic resources and usage in academic libraries in Ghana: Evidence from Koforidua Polytechnic and All Nations University College, Ghana', Journal of Education and Practice 6(33), 33-38.

Al-Ansari, H. 2006, 'Internet use by the faculty members of Kuwait University', The Electronic Library 24(6), 791-803. https://doi.org/10.1108/02640470610714224

Al-Shanbari, H. \& Meadows, A.J., 1995, 'Problems of communication and information handling among scientists and engineers in Saudi universities', Journal of Information Science 21(6), 473-478. https://doi.org/10.1177/016555159502100606

Amankwah, P.B., 2014, 'Use of electronic resources by undergraduate students of the Ghana Institute of Management and Public Administration', MA dissertation, Dept. of Information Studies, University of Ghana, viewed 18 November 2016, from http://hdl.handle.net/123456789/6989

Ani, O.E., Edem, M.B. \& Ottong, E.J., 2010, 'Analysis of internet access and use by academic staff in the University of Calabar, Calabar, Nigeria', Library Management 31(7), 535-545. https://doi.org/10.1108/01435121011071229

Ani, O.E., Ngulube, P. \& Onyancha, B., 2014, 'Effect of accessibility and utilisation of electronic information resources on productivity of academic staff in selected Nigerian universities', Science Research 2(6), 166-171. https://doi.org/10.11648/j. sr.20140206.13

Bashorun, M.T., Isah, A. \& Adisa, M.Y., 2011, 'User perception of electronic resources in the University of Ilorin, Nigeria (UNILORIN)', Journal of Emerging Trends in Computing and Information Sciences 2(11), 554-562, viewed 06 July 2016, from http://www.cisjournal.org/journalofcomputing/archive/vol2no11/ vol2no11_1.pdf

Borteye, W. \& Dadzie, P.S., 2015, 'Awareness and use of open access journals by graduate students of the University of Ghana', Innovation: Journal of Appropriate Librarianship and Information Work in Southern Africa, (abstract), 2015(50), viewed 23 April 2017, from http://journals.co.za/content/innovation/2015/50/ EJC174761

Dadzie, P.S., 2005, 'Electronic resources: Access and usage at Ashesi University College', Campus-Wide Information Systems 22(5), 290-297. https://doi.org/ 10.1108/10650740510632208

Dadzie, P.S. \& Van der Walt, T., 2015, 'Access and use of digital resources: A survey of their value for faculty in three Ghanaian universities', Libri, (abstract), 65(1), viewed 25 April 2017, from https://www.researchgate.net/publication/276389952 Access_and_Use_of_Digital_Resources_A_Survey_of_Their_Value_for_Faculty in_Three_Ghanaian_Universities

Davis, F.D., 1989, 'Perceived usefulness, perceived ease of use, and user acceptance of information technology', MIS Quarterly 13(3), 319-340. https://doi.org/10.2307/ 249008

Deng, H., 2010, 'Emerging patterns and trends in utilising electronic resources in a higher education environment: An empirical analysis', New Library World 111(3/4), 87-103. https://doi.org/10.1108/03074801011027600

De Vicente, A., Crawford, J. \& Clink, S., 2004, 'Use and awareness of electronic information services by academic staff at Glasgow Caledonian University', Library Review 53(8), 401-407. https://doi.org/10.1108/00242530410556238
Dzandza, P. \& Alemna, A., 2011, 'Challenges and prospects of consortia: A case study of the CARLIGH', Alexandria 22(1), 19-28. https://doi.org/10.7227/ ALX.22.1.3

English Oxford Living Dictionaries, 2016, Definition of learning in English: Learning, Oxford University Press, Oxford, viewed 18 November 2016, from https://en. oxforddictionaries.com/definition/learning

Falk, H., 2003, 'Electronic campus', The Electronic Library 21(1), 63-66.

Gakibayo, A., Ikoja-Odongo, J.R. \& Okello-Obura, C., 2013, 'Electronic information resources utilisation by students in Mbarara University Library', Library Philosophy and Practice (e-journal) 869, 1-26, viewed 20 June 2016, from http:// digitalcommons.unl.edu/libphilprac/869/

Heterick, B., 2002, Faculty attitudes toward electronic resources, viewed 25 October 2016, from https://er.educause.edu/articles/2002/1/faculty-attitudestoward-electronic-resources

IFLA Acquisition and Collection Development Section (ed.), 2012, Key issues for e-resource collection development: A guide for libraries, viewed 05 Novembe 2016, from http://www.ifla.org/files/assets/acquisition-collection-development/ publications/Electronic-resource-guide.pdf

Kalusopa, T., 2011, 'Developing an e-records readiness framework for labou organisations in Botswana', PhD thesis, Dept. of Information Science, University of South Africa.

Kaminer, N., 1997, 'Scholars and the use of the Internet', Library and Information Science Research 19(4), 329-345. https://doi.org/10.1016/S0740-8188(97) 90024-4

Kumar, R., 2005, Research methodology: A step-by-step guide for beginners, 2nd edn., SAGE, London.

Kwadzo, G., 2015, 'Awareness and usage of electronic databases by geography and resource development and information studies graduate students in the University of Ghana', Library Philosophy and Practice (e-journal) 1210 $1-28$, viewed 13 November 2016, from http://digitalcommons.unl.edu/ libphilprac/1210

Kwafoa, P.N.Y., Imoro, O. \& Afful-Arthur, P., 2014, 'Assessment of the use of electronic resources among administrators and faculty in the University of Cape Coast', Library Philosophy and Practice (e-journal) 1094, 1-18, viewed 05 November 2016 from http://digitalcommons.unl.edu/libphilprac/1094

Manda, P.A., 2005, 'Electronic resource usage in academic and research institutions in Tanzania', Information Development 21(4), 269-282, viewed 10 November 2016 from http://idv.sagepub.com/content/21/4/269.full.pdf+html

Nwezeh, C.M.T., 2010, 'The impact of Internet use on teaching, learning and research activities in Nigerian universities: A case study of Obafemi Awolowo University', The Electronic Library 28(5), 688-701. https://doi.org/10.1108/0264047101 1081960

Obeng-Koranteng G. \& Dzandu, M. 2013, 'Evaluation of the use of electronic resources by agricultural research scientists in Ghana: A study of the Food
Research Institute and Animal Research Institute', UGSpace, (abstract), viewed 08 Research Institute and Animal Research Institute', UGSpace, (abstract), view
December 2016, from http://ugspace.ug.edu.gh/handle/123456789/7689

Ojedokun, A.A. \& Owolabi, E.O., 2003, 'Internet access competence and the use of the Internet for teaching and research activities by University of Botswana academic staff', African Journal of Library, Archives and Information Science 13(1), 43-54.

Okello-Obura, C.,2010, 'Assessment of the problems LIS postgraduate students face in accessing e-resources in Makerere University, Uganda', Collection Building 29(3), 98-105. https://doi.org/10.1108/01604951011060385

Okello-Obura, C. \& Ikoja-Odongo, J.R., 2010, 'Electronic information seeking among LIS postgraduate students at Makerere University, Uganda', Library Philosophy and Practice (e-journal) 499, 1-13, viewed 11 December 2016, from $\mathrm{http}$ ://digitalcommons. unl.edu/cgi/viewcontent.cgi? http://digital

Okello-Obura, C. \& Magara, E, 2008, 'Electronic information access and utilisation by Makerere University students in Uganda', Evidence Based Library and Information Practice 3(3), 39-56. https://doi.org/10.18438/B8ZS58

Okiki, O.C., 2012, 'Electronic information resources awareness, attitude and use by academic staff members of University of Lagos, Nigeria', Library Philosophy and Practice (e-journal) 834, 1-8, viewed 09 January 2017, from http://digitalcommons. unl.edu/cgi/viewcontent.cgi?article=2110andcontext=libphilprac

Ozoemelem, O.A., 2009, 'Use of electronic resources by postgraduate students of the Department of Library and Information Science of Delta State University, Abraka, Nigeria', Library Philosophy and Practice (e-journal) 301, 1-23.

Rassiya, K. \& Chinnasamy, K., 2014, 'Information required for e-resources services provided by academic library', International Journal of Interdisciplinary and Multidisciplinary Studies (IJIMS) 1(6), 140-146.

Rehman, S. \& Ramzy, V., 2004, 'Awareness and use of digital information resources', Library Review 53(3), 150-156.

Renwick, S., 2005, 'Knowledge and use of electronic information resources by medical science faculty at the University of the West Indies', Journal of Medical Library Association 93(1), 21-31.

Rolinson, J., Meadows, A.J. \& Smith, H., 1995, 'Use of information technology by biological researchers', Journal of Information Science 21(2), 133-139. https://doi. org/10.1177/016555159502100207

Saunders, M., Lewis, P. \& Thornhill, A., 2012, Research methods for business students, 6 th edn., Pearson, London.

Shuttleworth, M., 2008, Definition of research, viewed 01 March 2017, from https:// explorable.com/definition-of-research 
Tahir, M., Mahmood, K. \& Shafique, F., 2010, 'Use of electronic information resources and facilities by humanities scholars', The Electronic Library 28(1), 122-136. and facilities by humanities scholars', The
https://doi.org/10.1108/02640471011023423

Thistoll, A.M., 2011, 'A grounded theory of preneurial agency in information technology creation', PhD thesis, School of Information Management, Victoria University of Wellington.

Vasishta, S. \& Jyoti, N., 2007, Harnessing electronic information resources through prospective consortia approach: A national necessity, viewed 01 March 2017, from http://eprints.rclis.org/13464/1/Harnessing_Electronic_Information_Resources through_Prospective_Consortia_Approach.pdf

Venkatesh, V., Morris, M.G., Davis, G.B. \& Davis, F.D., 2003, 'User acceptance of information technology: Toward a unified view', MIS Quarterly 27(3), 425-478. https://doi.org/10.2307/30036540
Vibert, N., Rouet, J.-F., Ros, C., Ramond, M. \& Deshoullieres, B., 2007, 'The use of online electronic information resources in scientific research: The case of neuroscience', Library and Information Science Research 29(4), 508-532. https:// doi.org/10.1016/j.lisr.2007.05.001

Watts, C. \& Ibegbulam, I., 2006, 'Access to electronic healthcare information resources in developing countries: Experiences from the Medical Library, College of Medicine, University of Nigeria', IFLA Journal 32(1), 54-61. https://doi. org/10.1177/0340035206063903

Yang, Z.Y. \& Li, Y., 2015, 'University faculty awareness and attitudes towards open access publishing and the institutional repository: A case study', Journal of Librarianship and Scholarly Communication 3(1) eP1210 https://doi. org/10.7710/2162-3309.1210

Yin, R.K., 2003, Case study research: Design and methods, 3rd edn., Sage, London. 